\title{
Spatial reach of the local field potential is frequency dependent
}

\author{
Szymon Łęski ${ }^{12^{*}}$, Henrik Lindén ${ }^{2}$, Tom Tetzlaff ${ }^{2}$, Klas H Pettersen², Gaute T Einevoll ${ }^{2}$ \\ From Twentieth Annual Computational Neuroscience Meeting: CNS*2011 \\ Stockholm, Sweden. 23-28 July 2011
}

The local field potential (LFP), the low-frequency part of the extracellularly recorded electric potential, is a signal commonly used to study the activity of neural populations. However, it is not clear how local the 'local' field potential in fact is, i.e., how large the populations are which contribute to the signal at a given point [1]. The spatial range of LFP will naturally depend on the spatial range of correlations in the neuronal dynamics, which may be different in different frequency bands. However, we expect that also the inherent low-pass filtering in the neuronal cables, which stems from the properties of the cable equation [2], will contribute to the frequency dependence of the spatial range of the LFP.
To investigate how dendritic filtering affects the spatial range of different frequency components of the LFP we simulated a population of morphologically reconstructed neurons homogeneously distributed within a disc of radius $R=1 \mathrm{~mm}$ (Figure 1A). The cells were driven by noise input of varying degree of correlation. We calculated the LFP at the center of the disc. We defined the reach of the LFP as radius $r<R$ such that the cells located closer than $r$ account for $95 \%$ of the power of the LFP. We found that for some combinations of neuron morphology, stimulation pattern, and degree of correlation, the reach of the high-frequency $(>100 \mathrm{~Hz})$ components can be even four times smaller than the reach of the lowfrequency $(<50 \mathrm{~Hz})$ components (Figure 1B).

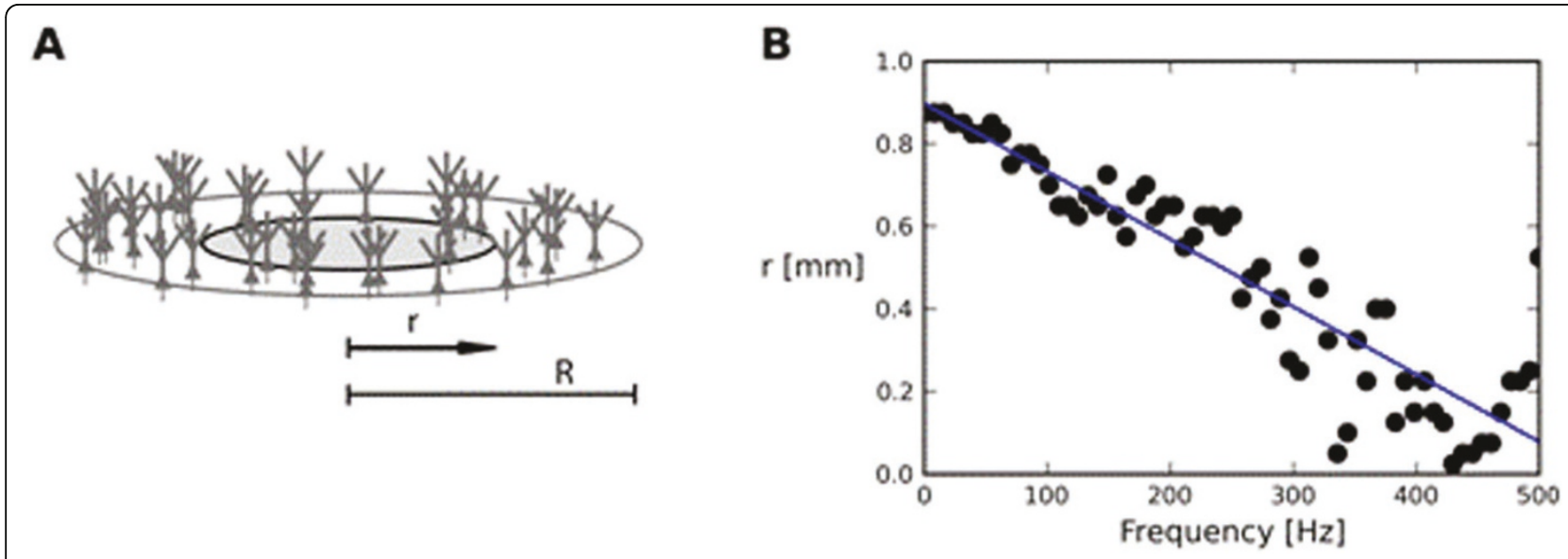

Figure $1 \mathrm{~A}$. Model setup, $r$ (reach) and $R$ defined in text. B. The reach $r$ as a function of LFP frequency for a population of layer 5 pyramidal neurons stimulated basally. The input correlation is $10 \%$ (each pair of neurons shares on average $10 \%$ of synaptic currents), LFP measured at the soma level.

\footnotetext{
* Correspondence: s.leski@nencki.gov.pl

'Department of Neurophysiology, Nencki Institute of Experimental Biology,

Warsaw, 02-093, Poland

Full list of author information is available at the end of the article
}

\section{Biomed Central}

C 2011 Lindén et al; licensee BioMed Central Ltd. This is an open access article distributed under the terms of the Creative Commons Attribution License (http://creativecommons.org/licenses/by/2.0), which permits unrestricted use, distribution, and reproduction in any medium, provided the original work is properly cited. 
The explanation of the effect is the following: consider a neuron stimulated with a sinusoidal input current (frequency $f$ ) at one point in the dendritic tree. The distribution of the return currents depends on $f$, with typically more local return currents for large $f$, see [3]. Therefore the 'critical distance', where the dipole approximation of the LFP becomes valid, decreases with $f$. We derived a simplified population model that accounts for the frequency dependence of the 'critical distance'. The model can be studied analytically and explains the frequency dependence of the LFP reach for both uncorrelated and correlated synaptic input.

\section{Acknowledgements}

We acknowledge financial support from The Research Council of Norway (eVita, Yggdrasil) and Scholarship and Training Fund (EEA/Norway grants).

\section{Author details}

'Department of Neurophysiology, Nencki Institute of Experimental Biology, Warsaw, 02-093, Poland. 'Department of Mathematical Sciences and Technology, Norwegian University of Life Sciences, Ås, 1432, Norway.

Published: 18 July 2011

\section{References}

1. Lindén $H$, Pettersen KH, Tetzlaff $T$, Potjans $T$, Denker M, Diesmann M, Grün S, Einevoll GT: Estimating the spatial range of local field potentials in a cortical population model. BMC Neuroscience 2009, 10:P224.

2. Pettersen $\mathrm{KH}$, Einevoll GT: Amplitude Variability and Extracellular LowPass Filtering of Neuronal Spikes. Biophys J 2008, 94:784-802.

3. Lindén $\mathrm{H}$, Pettersen $\mathrm{KH}$, Einevoll GT: Intrinsic dendritic filtering gives lowpass power spectra of local field potentials. J Comput Neurosci 2010, 29:423-444.

\section{doi:10.1186/1471-2202-12-S1-P88}

Cite this article as: $Ł e ̨ s k i$ et al:: Spatial reach of the local field potential is frequency dependent. BMC Neuroscience 2011 12(Suppl 1):P88.

\section{Submit your next manuscript to BioMed Central} and take full advantage of:

- Convenient online submission

- Thorough peer review

- No space constraints or color figure charges

- Immediate publication on acceptance

- Inclusion in PubMed, CAS, Scopus and Google Scholar

- Research which is freely available for redistribution

Submit your manuscript at www.biomedcentral.com/submit
Ciomed Central 